\title{
The effect of floating covers on gas emissions from liquid pig manure
}

\author{
Raimundas Matulaitis $^{1 *}$, Violeta Juškiené1 ${ }^{1}$ and Remigijus Juška1
}

Livestock manure is the source of different pollutant gases that can generate soil acidification, eutrophication, and contribute to global warming, or have a negative impact on health. Covers can control gas emissions from manure, but their impact is still under discussion. The aim of this experiment was to study the effect of different covers on methane $\left(\mathrm{CH}_{4}\right)$, nitric oxide (NO), hydrogen sulfide $\left(\mathrm{H}_{2} \mathrm{~S}\right)$, ammonia $\left(\mathrm{NH}_{3}\right)$, carbon monoxide $(\mathrm{CO})$, and carbon dioxide $\left(\mathrm{CO}_{2}\right)$ emissions from liquid pig manure. Six types of floating covers were tested: light expanded clay aggregate (leca), peat, sunflower oil, sawdust, straw, and plastic film. Manure was stored at 5, 15 , and $25^{\circ} \mathrm{C}$ for $37 \mathrm{~d}$. Gas emissions were measured from the headspaces of the dynamic chambers. The results of our study showed that both cover and temperature have a noticeable impact on gas emissions from liquid pig manure. The plastic film cover was the most efficient at all tested temperatures because it reduced emissions of all the measured gases. In this case, mean emission reductions were: $\mathrm{CH}_{4} 91.5 \%(\mathrm{P}<0.01), \mathrm{NO} 92.0 \%(\mathrm{P}<$ 0.05), $\mathrm{H}_{2} \mathrm{~S} 78.1 \%(\mathrm{P}<0.05), \mathrm{NH}_{3} 54.7 \%(\mathrm{P}<0.01), \mathrm{CO} 98.4 \%(\mathrm{P}<0.01)$, and $\mathrm{CO}_{2} 67.1 \%(\mathrm{P}<0.01)$. Other covers had an inconsistent impact on separate gas emissions. However, covers generally helped to decrease $\mathrm{NH}_{3}, \mathrm{H}_{2} \mathrm{~S}$, and $\mathrm{CO}_{2}$ emissions .

Key words: Emission reduction, livestock excreta, pig manure, pollutant gases.

\section{INTRODUCTION}

Large quantities of different pollutant gases can be emitted during animal manure storage. Livestock manure is the emission source of such gases as ammonia $\left(\mathrm{NH}_{3}\right)$, methane $\left(\mathrm{CH}_{4}\right)$, carbon dioxide $\left(\mathrm{CO}_{2}\right)$, hydrogen sulfide $\left(\mathrm{H}_{2} \mathrm{~S}\right)$, carbon monoxide $(\mathrm{CO})$, and nitric oxide $(\mathrm{NO})$. It was estimated that livestock excreta accounts for more than $80 \%$ of $\mathrm{NH}_{3}$ emissions from European agriculture, and it contributes 5\% of total $\mathrm{CH}_{4}$ emissions (EEA, 2009; Sommer et al., 2009). The emission of $\mathrm{NH}_{3}$ and $\mathrm{CH}_{4}$ can cause serious environmental problems and/or health risks. The emission of $\mathrm{NH}_{3}$ leads to soil acidification and eutrophication (European Commission, 2011). Similar to $\mathrm{CO}_{2}$, methane contributes to global warming (IPCC, 2006). Both $\mathrm{NH}_{3}$ and $\mathrm{H}_{2} \mathrm{~S}$ have a negative impact on health. Likewise, $\mathrm{CO}$ and $\mathrm{NO}$ can have an adverse effect on human health. Nitric oxide is also involved in the formation of ozone (EEA, 2009). Measures should therefore be taken to control gas emissions from manure and minimize or eliminate the negative impact on the environment.

A variety of options exist for mitigating gas emissions from manure. However, methods differ in effectiveness,

${ }^{1}$ Lithuanian University of Health Sciences, Institute of Animal Science, R. Žebenkos str. 12, LT-82317 Baisogala, Radviliskis distr., Lithuania."Corresponding author (ramatulaitis@gmail.com).

Received: 1 August 2014.

Accepted: 9 February 2015.

doi:10.4067/S0718-58392015000200013 cost, practicality, and expertise required to operate them efficiently. Good results were obtained with covers, at least to reduce $\mathrm{NH}_{3}$ emissions (Brink et al., 2005; Webb et al., 2006; Ndegwa et al., 2008; VanderZaag et al., 2009). Stationary (a 'tight' lid, roof or tent structure) or floating covers can be used. Stationary covers are much more expensive than floating covers, and it is difficult to install them on large stores (Webb et al., 2006). There is a range of floating covers that could reduce $\mathrm{NH}_{3}$ emission from stored slurries. The impact of covers on the emission of gases other than $\mathrm{NH}_{3}$ is still under discussion. The study by Bicudo et al. (2004) showed that covers can decrease $\mathrm{H}_{2} \mathrm{~S}$ emission. Research by Ambus and Petersen (2005), Petersen et al. (2005), Hansen et al. (2006), and Petersen and Ambus (2006) demonstrated that covers can reduce $\mathrm{CH}_{4}$ emission. However, reduction was not achieved for all types of covers. The study by Petersen and Ambus (2006) showed that a cover of expanded clay product (leca) was not effective to reduce $\mathrm{CH}_{4}$ emission. Petersen et al. (2009) also noticed that nitrous oxide $\left(\mathrm{N}_{2} \mathrm{O}\right)$ emission can increase as a consequence of oxidizing processes in the cover. VanderZaag et al. (2009) found that the use of covers might not only increase $\mathrm{N}_{2} \mathrm{O}$ emission, but also $\mathrm{CO}_{2}$. Furthermore, the study by Amon et al. (2006) demonstrated that the type of cover can highly influence emission. The study showed that covering the slurry store with a layer of chopped straw, instead of a wooden cover, increased $\mathrm{NH}_{3}$ and greenhouse gas (GHG) emissions. Berg et al. (2006) also found increased GHG after using straw and granules as covers. Therefore, the question is whether using covers could help to reduce $\mathrm{NH}_{3}$ emission, 
but increase the emission of other gases, or if the common effect of covers could be beneficial.

The aim of the current experiment was to investigate the influence of different types of floating covers on $\mathrm{CH}_{4}$, $\mathrm{NO}, \mathrm{H}_{2} \mathrm{~S}, \mathrm{NH}_{3}, \mathrm{CO}$, and $\mathrm{CO}_{2}$ emissions from liquid pig manure.

\section{MATERIALS AND METHODS}

\section{Experimental design}

The current study was carried out at the Lithuanian University of Health Sciences, Institute of Animal Science (Baisogala, Lithuania) under environmentally controlled conditions.

Fresh liquid pig manure was collected from the floor of the pens on the farm of the Institute of Animal Science. Pigs were housed in naturally ventilated buildings with a scraper manure removal system. Pigs were fed concentrates twice a day. The same day manure was transported to the laboratory and homogenized; 72 vessels were immediately filled with $1.0 \mathrm{~kg}$ manure each. All the vessels were identical, cylindrical, $110 \mathrm{~mm}$ height, 169 $\mathrm{mm}$ inner diameter, and with $2.1 \mathrm{~L}$ capacity. Half of the vessels were left uncovered, while the rest were covered with a separate floating cover. Covers were applied directly onto the manure surface. Six types of floating covers were tested: light expanded clay aggregate (leca), peat, sunflower oil, softwood sawdust, straw, and black plastic film. Leca was in granular form with a nominal diameter of 10 to $20 \mathrm{~mm}$ and low density $\left(250 \mathrm{~kg} \mathrm{~m}^{-3}\right)$. Sunflower oil was an ordinary food product that is biodegradable, that is, harmless. Wheat straw was chopped to a $6-\mathrm{cm}$ length. The thickness of each cover was as follows: $40 \mathrm{~mm}$ leca, $40 \mathrm{~mm}$ peat, $40 \mathrm{~mm}$ sawdust, $40 \mathrm{~mm}$ straw, $2 \mathrm{~mm}$ sunflower oil, and $0.1 \mathrm{~mm}$ plastic film (for comparisons, the thickness of permeable covers was the same). After all the vessels were filled with homogenized manure and covers were applied, samples were stored in open vessels in three thermostatic rooms and measurements were taken. Covered and uncovered manures were stored under the same conditions. Room temperatures were maintained at $5 \pm 1{ }^{\circ} \mathrm{C}, 15 \pm 1{ }^{\circ} \mathrm{C}$, and $25 \pm 1{ }^{\circ} \mathrm{C}$. Two replicates were performed for the manure covered with a separate cover and with no cover at each storage temperature. During the experimental period, gas emissions were measured and manure was analyzed for chemical composition. The gas measurement period extended until a tight crust settled on the surface of uncovered manure; the length of the gas measurement period was $37 \mathrm{~d}$ (crust acts as a cover, consequently comparing emissions between covered and crusted manure would be counterproductive).

\section{Gas measurement}

The dynamic chamber method and gas measuring devices were adopted by using laboratory simulation to analyze gas emissions from the stored manure with a portable multigas measuring instrument (Dräger X-am 7000, Dräger Safety AG \& Co, Lübeck, Germany) for 0 to $200 \pm 1 \mathrm{~mL}$ $\mathrm{NH}_{3} \mathrm{~m}^{-3}, 0$ to $100 \pm 1 \mathrm{mLNO} \mathrm{m}^{-3}, 0$ to $100 \pm 1 \mathrm{mLH}_{2} \mathrm{~S} \mathrm{~m}^{-3}$, 0 to $44000 \mathrm{~mL} \mathrm{CH}_{4} \mathrm{~m}^{-3} \pm 1 \%$; a multi-gas monitor (M40, Industrial Scientific Corporation, Oakdale, Pennsylvania, USA) for 0 to $999 \pm 1 \mathrm{~mL} \mathrm{CO} \mathrm{m}^{-3}, 0$ to $500 \pm 1 \mathrm{~mL} \mathrm{H}_{2} \mathrm{~S}$ $\mathrm{m}^{-3}, 0$ to $50000 \mathrm{~mL} \mathrm{CH}_{4} \mathrm{~m}^{-3} \pm 2 \%$; and a data logger (Almemo 2890-9, Ahlborn Mess und Regelungstechnik $\mathrm{GmbH}$, Holzkirchen, Germany) for 0 to $10000 \mathrm{~mL} \mathrm{CO}_{2}$ $\mathrm{m}^{-3} \pm 2 \%$. During gas concentration measurements, each vessel was temporally converted into a dynamic chamber by closing it with an airtight lid. The lid had two air inlet and outlet ports as described in the study by Dinuccio et al. (2008). The air outlet port was connected to gas measuring devices, a sampling pump $\left(0.25 \mathrm{~L} \mathrm{~min}^{-1}\right.$; SP 40 , Industrial Scientific Corporation), and flow meter (0 to $4 \mathrm{~L} \mathrm{~min}^{-1} \pm$ $0.1 \mathrm{~mL}$; RDS-4, Steklopribor, Kiev, Ukraine) (Figure 1). The headspace between the manure surface and the lid was ventilated by pumping air to create a constant $0.015 \mathrm{~m}^{3} \mathrm{~h}^{-1}$ air flow rate through the dynamic chamber. Incoming air to the chamber and exhaust air, that leaves each chamber, was sampled and gas concentrations were measured every minute. The mean of the six recorded values was calculated and considered representative of the individual measurement. The vessels were kept open until the next gas measurement; this is similar to the studies by Dinuccio et al. (2008) and Wang et al. (2010). Gas concentrations in each vessel were measured twice a week.

The emission rate of the different gases was quantified using the following Equation [1]:

$$
F=Q M p(C e x-\operatorname{Cin}) R^{-1}(T+273)^{-1} A^{-1}
$$
where $F$ is the gas emission rate $\left(\mathrm{mg} \mathrm{m}^{-2} \mathrm{~h}^{-1}\right)$ under

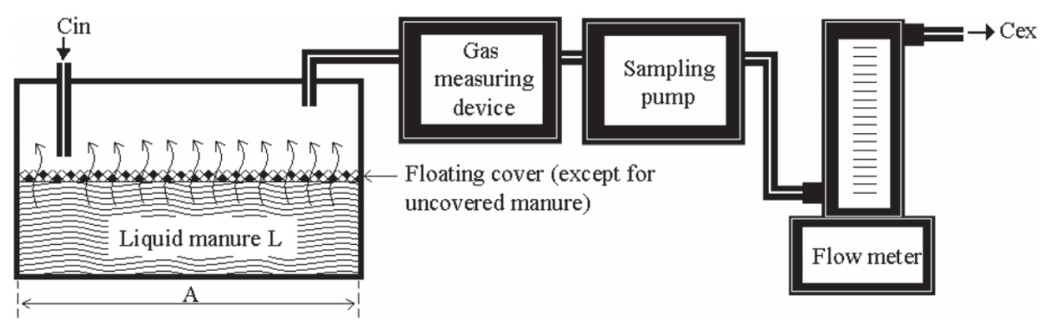

Cin: Gas concentration of air inlet into the chamber; Cex: gas concentration of air outlet from the chamber.

Figure 1. Schematic diagram of the gas measuring system. 
standard conditions $\left(25^{\circ} \mathrm{C}\right.$ and $\left.100 \mathrm{kPa}\right), Q$ is the air flow rate through the gas measuring system $\left(\mathrm{m}^{3} \mathrm{~h}^{-1}\right), M$ is gas mole mass $\left(\mathrm{g} \mathrm{mol}^{-1}\right), p$ is gas pressure $(\mathrm{kPa})$, Cin is the gas concentration of the air inlet into the chamber $(\mathrm{mL}$ $\left.\mathrm{m}^{-3}\right)$, Cex is the gas concentration of the air outlet from the chamber $\left(\mathrm{mL} \mathrm{m}^{-3}\right), R$ is the gas constant $\left(8.314 \mathrm{~J} \mathrm{~K}^{-1}\right.$ $\left.\mathrm{mol}^{-1}\right), T$ is gas temperature $\left({ }^{\circ} \mathrm{C}\right)$, and $A$ is the surface area of manure $\left(\mathrm{m}^{2}\right)$.

\section{Analysis of manure}

At the beginning and end of the study, manure samples were taken from each vessel and analyzed for $\mathrm{pH}$, total solids (TS), volatile solids (VS), ash, total Kjeldahl $\mathrm{N}$ (TKN), and total ammonia $\mathrm{N}$ (TAN). The $\mathrm{pH}$ was measured with a $\mathrm{pH}$ meter $(-2$ to $16 \pm 0.05$; HI 98128 , HANNA Instruments, Woonsocket, Rhode Island, USA). Total solids content was determined after drying manure in an electric oven (Memmert ULE-500, Memmert GmbH + Co. KG, Schwabach, Germany) at $105 \pm 2{ }^{\circ} \mathrm{C}$ for $24 \mathrm{~h}$ (Peters et al., 2003). Ash content and volatile solids were calculated after burning total solids in a muffle furnace (L1/12, Nabertherm GmbH, Lilienthal, Germany) at 550 ${ }^{\circ} \mathrm{C}$ for $4 \mathrm{~h}$. Total $\mathrm{N}$ was determined with a digester and by distillation (Tecator 2006 digestion unit and Kjeltec 1002 distilling unit, Foss Tecator AB, Höganäs Sweden) according to the Kjeldahl method (Peters et al., 2003); total ammonia $\mathrm{N}$ was determined by distillation. All values were calculated on the basis of natural manure.

\section{Statistical analysis}

Statistical analysis was performed with the Statistica (Data Analysis Software System, Version 7.0; StatSoft, Tulsa, Oklahoma, USA) software package. Differences were investigated by Student's (t) criterion as well as the ANOVA procedure. Assumption of equal variance of separate groups was verified by Bartlett's test. A significance level of $\mathrm{P} \leq 0.05$ was applied to all the statistics.

\section{RESULTS}

\section{Manure composition}

Water evaporation and adequate loss of initial manure weight occurred during the experimental period (Table 1). Covers reduced manure moisture loss. Water evaporation mostly decreased after manure was covered with plastic film, which was 7.9 to 18.4 times $(\mathrm{P}<0.01)$ lower compared with uncovered manure.

At the beginning of the experiment, fresh manure $\mathrm{pH}$ was slightly alkaline, but it changed during the storage period. The highest change in $\mathrm{pH}$ was detected for manure covered with sawdust at $25^{\circ} \mathrm{C}$; $\mathrm{pH}$ was 2.9 times $(\mathrm{P}<$ $0.05)$ lower compared with uncovered manure.

For most of the samples, total solids (TS) and volatile solids (VS) content increased at the end of the experiment. The highest change of TS and VS was detected in manure covered with sawdust at $15{ }^{\circ} \mathrm{C}$; TS and VS increased by more than 7.3 and 9.7 times $(\mathrm{P}<0.05)$, respectively, compared with uncovered manure. However, VS increase is relative and associated with water evaporation and therefore, with the loss of initial manure weight. During manure storage, biodegradation of volatile solids evolved. The increase in the amount of ash (in most samples) at the end of experiment confirms the above assumption. Physical and chemical characteristics of manure changed satisfactorily.

Table 1. Manure composition and its changes during the experiment.

\begin{tabular}{|c|c|c|c|c|c|c|c|c|c|}
\hline & & Storaoe & & & & & & & \\
\hline & & temperature & Weight & $\mathrm{pH}$ & TS & VS & Ash & TKN & TAN \\
\hline & & ${ }^{\circ} \mathrm{C}$ & $\mathrm{kg}$ & & & & $\mathrm{g} \mathrm{kg}^{-1}$ & & \\
\hline Fresh & & & 1.00 & 8.08 & 109.07 & 91.83 & 17.23 & 6.86 & 3.82 \\
\hline & & Chang & initial $\mathrm{w}$ & manure & & & & & \\
\hline & & & & & & $\%$ & & & \\
\hline No cover & & 5 & $\downarrow 31.28$ & $\uparrow 1.36$ & $\uparrow 43.96$ & $\uparrow 42.60$ & $\uparrow 53.38$ & $\downarrow 37.07$ & $\uparrow 16.53$ \\
\hline Cover & Leca & & $\downarrow 14.20$ & $\uparrow 5.31$ & $\uparrow 11.61$ & $\uparrow 12.77$ & $\uparrow 5.28$ & $\downarrow 31.51$ & $\uparrow 31.03$ \\
\hline & Peat & & $\downarrow 20.17$ & $\downarrow 0.49$ & $\uparrow 37.88$ & $\uparrow 38.66$ & $\uparrow 34.16$ & $\downarrow 42.86$ & $\uparrow 22.50$ \\
\hline & Sunflower oil & & $\downarrow 6.86$ & $\downarrow 14.60$ & $\uparrow 62.78$ & $\uparrow 75.97$ & $\uparrow 7.19$ & $\downarrow 57.33$ & $\downarrow 5.56$ \\
\hline & Sawdust & & $\downarrow 11.74$ & 0.00 & $\uparrow 65.57$ & $\uparrow 67.21$ & $\uparrow 57.66$ & $\downarrow 54.10$ & $\downarrow 5.00$ \\
\hline & Straw & & $\downarrow 6.36$ & $\downarrow 7.84$ & $\uparrow 29.05$ & $\uparrow 29.74$ & $\uparrow 26.40$ & $\downarrow 53.85$ & $\uparrow 8.51$ \\
\hline & Plastic film & & $\downarrow 1.70$ & $\uparrow 1.00$ & 0.00 & $\downarrow 0.75$ & $\uparrow 5.60$ & $\downarrow 48.94$ & $\uparrow 20.00$ \\
\hline No cover & & 15 & $\downarrow 18.87$ & $\downarrow 6.99$ & $\uparrow 11.60$ & $\uparrow 8.92$ & $\uparrow 27.05$ & $\downarrow 52.94$ & $\downarrow 8.15$ \\
\hline Cover & Leca & & $\downarrow 4.70$ & $\uparrow 0.93$ & $\uparrow 2.33$ & $\uparrow 2.54$ & $\uparrow 1.22$ & $\downarrow 49.32$ & $\uparrow 20.69$ \\
\hline & Peat & & $\downarrow 8.83$ & $\downarrow 7.61$ & $\uparrow 33.23$ & $\uparrow 33.61$ & $\uparrow 31.19$ & $\downarrow 36.36$ & $\uparrow 2.50$ \\
\hline & Sunflower oil & & $\downarrow 9.67$ & $\downarrow 14.49$ & $\uparrow 66.79$ & $\uparrow 80.47$ & $\uparrow 9.80$ & $\downarrow 65.33$ & $\uparrow 1.85$ \\
\hline & Sawdust & & $\downarrow 11.19$ & $\downarrow 10.94$ & $\uparrow 84.67$ & $\uparrow 86.53$ & $\uparrow 75.68$ & $\downarrow 47.54$ & $\downarrow 17.50$ \\
\hline & Straw & & $\downarrow 7.86$ & $\downarrow 12.87$ & $\downarrow 5.56$ & $\downarrow 7.44$ & $\uparrow 3.05$ & $\downarrow 67.95$ & $\downarrow 10.64$ \\
\hline & Plastic film & & $\downarrow 1.55$ & $\uparrow 1.58$ & $\downarrow 12.11$ & $\downarrow 14.39$ & $\uparrow 3.20$ & $\downarrow 57.45$ & $\uparrow 30.00$ \\
\hline No cover & & 25 & $\downarrow 12.60$ & $\downarrow 5.75$ & $\downarrow 10.23$ & $\downarrow 14.09$ & $\uparrow 11.33$ & $\downarrow 63.55$ & $\downarrow 12.67$ \\
\hline Cover & Leca & & $\downarrow 9.73$ & $\uparrow 1.86$ & $\uparrow 4.04$ & $\uparrow 2.84$ & $\uparrow 10.57$ & $\downarrow 45.21$ & $\uparrow 3.45$ \\
\hline & Peat & & $\downarrow 8.79$ & $\downarrow 12.15$ & $\uparrow 22.39$ & $\uparrow 18.09$ & $\uparrow 45.54$ & $\downarrow 41.56$ & $\downarrow 57.50$ \\
\hline & Sunflower oil & & $\downarrow 12.57$ & $\downarrow 11.33$ & $\uparrow 62.78$ & $\uparrow 74.11$ & $\uparrow 15.69$ & $\downarrow 70.67$ & $\uparrow 16.67$ \\
\hline & Sawdust & & $\downarrow 6.28$ & $\downarrow 16.47$ & $\uparrow 62.85$ & $\uparrow 61.63$ & $\uparrow 73.87$ & $\downarrow 49.18$ & $\downarrow 40.00$ \\
\hline & Straw & & $\downarrow 6.94$ & $\downarrow 13.22$ & $\downarrow 8.20$ & $\downarrow 10.88$ & $\uparrow 4.06$ & $\downarrow 65.38$ & $\downarrow 19.15$ \\
\hline & Plastic film & & $\downarrow 1.60$ & $\uparrow 5.87$ & $\downarrow 15.89$ & $\downarrow 18.15$ & $\downarrow 0.80$ & $\downarrow 61.70$ & $\uparrow 55.00$ \\
\hline
\end{tabular}

TS: Total solids (dry matter, DM), VS: volatile solids (organic matter), TKN: total Kjeldahl N, TAN: total ammonia N. 
Total $\mathrm{N}$ content decreased in all the samples at the end of the experiment. The highest change in initial TKN was found at $25{ }^{\circ} \mathrm{C}$ for manure covered with sunflower oil; it was $11.2 \%(\mathrm{P}<0.01)$ lower than uncovered manure. The highest amount of initial TKN remained in the manure covered with leca at $5{ }^{\circ} \mathrm{C}$; it tended to be $15.0 \%(\mathrm{P}=0.08)$ higher compared with uncovered manure.

Initial TAN content varied inconsistently depending on the type of cover and the temperature. The highest TAN increase was at $25^{\circ} \mathrm{C}$ for manure covered with plastic film. In contrast, the highest TAN decrease was found at the same temperature, but for manure with a peat cover. At 15 and $25^{\circ} \mathrm{C}$, TAN decreased when no cover was used, but the opposite occurred at the lowest temperature.

\section{Gas emissions}

Leca cover. The ANOVA procedure showed that leca cover had a significant impact on $\mathrm{H}_{2} \mathrm{~S}, \mathrm{CO}$, and $\mathrm{CO}_{2}$ emissions; it also tended to affect $\mathrm{NH}_{3}$ emission. Mean differences between $\mathrm{H}_{2} \mathrm{~S}, \mathrm{CO}$, and $\mathrm{CO}_{2}$ emissions from manure covered with leca resulted in a reduction of $74.0 \%$ $(\mathrm{P}<0.05), 57.1 \%(\mathrm{P}<0.05)$, and 40.4\% $(\mathrm{P}<0.01)$, respectively, compared with uncovered manure. The $\mathrm{NH}_{3}$ emission rates from manure with a leca cover tended to be $34.6 \%(\mathrm{P}=0.14)$ lower than uncovered manure. However, the leca cover was not the factor affecting $\mathrm{CH}_{4}$ and $\mathrm{NO}$ emissions.

Emission rates of all the mentioned gases depended on storage temperature. Generally, a higher emission was detected at a higher storage temperature (Table 2). The impact of covering manure on gas emissions depended on the temperature regime being used (Figure 2). The emissions of $\mathrm{H}_{2} \mathrm{~S}$ and $\mathrm{CO}_{2}$ decreased in all the temperature regimes after manure was covered with leca, but the highest reduction was at $5{ }^{\circ} \mathrm{C}$; it was $100.0 \%(\mathrm{P}<0.05)$ and $48.5 \%(\mathrm{P}<0.01)$ lower, respectively, than uncovered manure. Carbon monoxide emissions decreased only at 5 and $25^{\circ} \mathrm{C}$. The emission of $\mathrm{NH}_{3}$ from covered manure tended to reach the highest reduction at $5{ }^{\circ} \mathrm{C}$ compared with 5 and $25^{\circ} \mathrm{C}$.

Peat cover. Peat cover had a significant impact on $\mathrm{CH}_{4}$, $\mathrm{NH}_{3}, \mathrm{CO}$, and $\mathrm{CO}_{2}$ emissions. The emissions of $\mathrm{CH}_{4}$, $\mathrm{NH}_{3}$, and $\mathrm{CO}_{2}$ from covered manure were $88.5 \%(\mathrm{P}<$ $0.01)$, 43.8\% ( $\mathrm{P}<0.01)$, and 30.0\% ( $\mathrm{P}<0.01)$ lower, respectively, than uncovered manure. The $\mathrm{CO}$ emission was up to 6 times $(\mathrm{P}<0.01)$ higher in covered than uncovered manure. However, differences between NO and $\mathrm{H}_{2} \mathrm{~S}$ emission rates from covered and uncovered manure were not significant.

The emissions of $\mathrm{CH}_{4}$ and $\mathrm{NH}_{3}$ decreased in all the temperature regimes used after manure was covered with peat. The highest reduction of $\mathrm{CH}_{4}$ emission was at 5 ${ }^{\circ} \mathrm{C}$, which was $100.0 \%(\mathrm{P}<0.01)$ lower than uncovered manure. The highest reduction of $\mathrm{NH}_{3}$ emission was at $25^{\circ} \mathrm{C}$, which was $67.3 \%(\mathrm{P}<0.01)$ lower than uncovered manure. The emission of $\mathrm{CO}_{2}$ from covered manure decreased only at 5 and $25^{\circ} \mathrm{C}$. The highest increase of $\mathrm{CO}$ emissions was at $5^{\circ} \mathrm{C}$, and it was up to 15 times $(\mathrm{P}<0.01)$ higher than uncovered manure.

Sunflower oil cover. The sunflower oil cover had a significant impact on $\mathrm{NO}, \mathrm{H}_{2} \mathrm{~S}, \mathrm{NH}_{3}$, and $\mathrm{CO}$ emissions. The emissions of $\mathrm{NO}, \mathrm{H}_{2} \mathrm{~S}$, and $\mathrm{NH}_{3}$ from covered manure were 50.3\% ( $\mathrm{P}<0.05), 50.2 \%(\mathrm{P}<0.05)$, and $45.9 \%(\mathrm{P}<$ $0.01)$ lower, respectively, than uncovered manure. Carbon monoxide emission was 4.8 times $(\mathrm{P}<0.01)$ higher in covered manure than uncovered manure. However, the differences between $\mathrm{CH}_{4}$ and $\mathrm{CO}_{2}$ emission rates from covered and uncovered manure were not significant.

Table 2. Effect of floating covers and temperature on gas emission rates from liquid pig manure.

\begin{tabular}{|c|c|c|c|c|c|c|c|c|}
\hline \multirow[b]{2}{*}{ Manure } & & \multirow{2}{*}{$\begin{array}{c}\text { Storage } \\
\text { temperature }\end{array}$} & \multicolumn{6}{|c|}{ Emission rates $^{1}$} \\
\hline & & & $\mathrm{CH}_{4}$ & NO & $\mathrm{H}_{2} \mathrm{~S}$ & $\mathrm{NH}_{3}$ & $\mathrm{CO}$ & $\mathrm{CO}_{2}$ \\
\hline & & ${ }^{\circ} \mathrm{C}$ & & 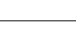 & -1 & $1^{-1}$ & & \\
\hline \multicolumn{2}{|l|}{ No cover } & 5 & 31.67 & 0.07 & 0.03 & 3.17 & 0.05 & 2726.71 \\
\hline \multirow[t]{6}{*}{ Cover } & Leca & & 0.00 & 0.00 & 0.00 & 0.32 & 0.00 & 1404.12 \\
\hline & Peat & & 0.00 & 0.01 & 0.00 & 2.81 & 0.81 & 1383.80 \\
\hline & Sunflower oil & & 0.00 & 0.33 & 0.35 & 2.42 & 1.57 & 1474.04 \\
\hline & Sawdust & & 0.00 & 0.00 & 0.00 & 3.54 & 0.00 & 123.16 \\
\hline & Straw & & 0.00 & 0.10 & 0.00 & 3.97 & 0.02 & 821.12 \\
\hline & Plastic film & & 0.00 & 0.02 & 0.05 & 0.29 & 0.00 & 1564.69 \\
\hline No cover & & 15 & 138.09 & 0.67 & 3.71 & 9.97 & 0.11 & 7230.11 \\
\hline \multirow[t]{6}{*}{ Cover } & Leca & & 66.63 & 0.34 & 0.22 & 1.85 & 0.21 & 4977.19 \\
\hline & Peat & & 6.08 & 0.32 & 0.09 & 6.37 & 0.35 & 5527.51 \\
\hline & Sunflower oil & & 175.15 & 1.61 & 9.47 & 16.24 & 1.05 & 3949.03 \\
\hline & Sawdust & & 0.00 & 0.06 & 0.05 & 6.12 & 0.00 & 417.88 \\
\hline & Straw & & 101.12 & 0.13 & 0.49 & 7.21 & 0.05 & 1546.42 \\
\hline & Plastic film & & 6.15 & 0.02 & 0.09 & 1.39 & 0.00 & 3205.40 \\
\hline No cover & & 25 & 282.13 & 5.54 & 20.62 & 31.75 & 0.86 & 12845.30 \\
\hline \multirow[t]{6}{*}{ Cover } & Leca & & 162.59 & 1.90 & 0.75 & 4.76 & 0.67 & 10757.76 \\
\hline & Peat & & 75.59 & 12.53 & 8.59 & 10.37 & 4.25 & 16411.17 \\
\hline & Sunflower oil & & 404.16 & 2.68 & 16.90 & 25.51 & 0.55 & 8849.57 \\
\hline & Sawdust & & 0.00 & 10.19 & 5.11 & 7.65 & 2.96 & 3125.10 \\
\hline & Straw & & 412.64 & 2.56 & 2.25 & 14.13 & 1.60 & 7348.44 \\
\hline & Plastic film & & 18.30 & 0.29 & 0.40 & 4.78 & 0.02 & 4400.48 \\
\hline
\end{tabular}

${ }^{1}$ Mean value for 37-d measurement period. 

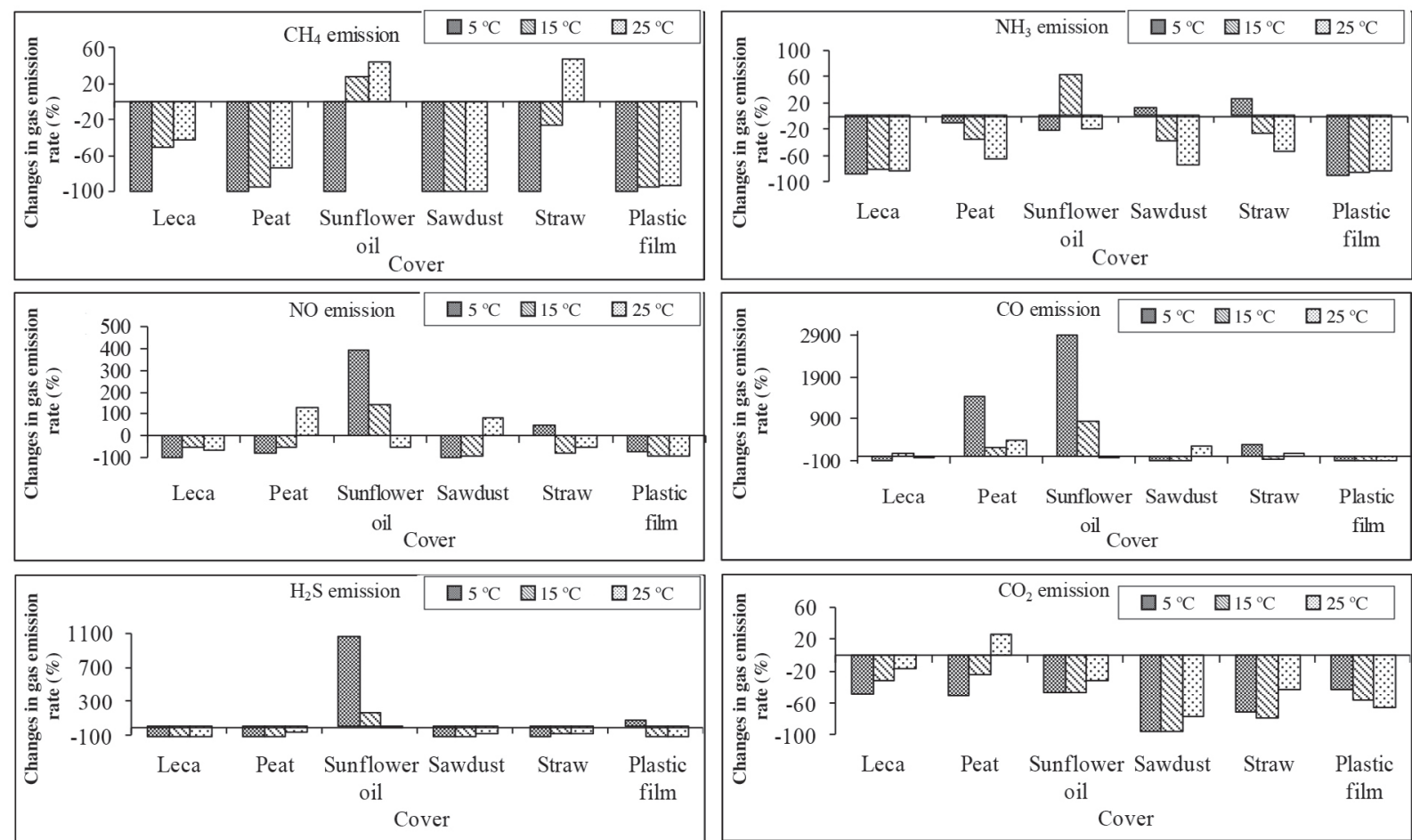

Figure 2. Effect of covers on gas emissions from manure at different storage temperatures.

Raising the temperature was the factor that sustained the reduction of $\mathrm{NO}$ and $\mathrm{H}_{2} \mathrm{~S}$ emission by using sunflower oil cover. In contrast, the highest reduction of $\mathrm{NH}_{3}$ emission by the cover was at $5{ }^{\circ} \mathrm{C}$, which was $23.8 \%$ (P $<0.01)$ lower than uncovered manure stored at 15 and 25 ${ }^{\circ} \mathrm{C}$. The increase of $\mathrm{CO}$ emission from covered manure at $5{ }^{\circ} \mathrm{C}$ was 3.4 times $(\mathrm{P}<0.01)$ higher than at $15^{\circ} \mathrm{C}$. The highest increase of $\mathrm{CO}$ emission after covering the manure was at $5^{\circ} \mathrm{C}$, which was 3.4 times $(\mathrm{P}<0.01)$ higher than at $15^{\circ} \mathrm{C}$.

Sawdust cover. The sawdust cover had a significant impact on $\mathrm{CH}_{4}, \mathrm{H}_{2} \mathrm{~S}, \mathrm{NH}_{3}$, and $\mathrm{CO}_{2}$ emissions; it also tended to affect $\mathrm{CO}$ emission. These emissions from covered manure were 100.0\% $(\mathrm{P}<0.01), 87.6 \%(\mathrm{P}<$ $0.01), 73.4 \%(\mathrm{P}<0.01)$, and $71.6 \%(\mathrm{P}<0.01)$ lower, respectively, than uncovered manure. The $\mathrm{CO}$ emission rates from manure with a sawdust cover tended to be 3.1 times $(\mathrm{P}=0.05)$ higher compared with uncovered manure. However, the sawdust cover was not the factor affecting NO emission.

The emissions of $\mathrm{CH}_{4}, \mathrm{H}_{2} \mathrm{~S}$, and $\mathrm{CO}_{2}$ decreased in all the temperature regimes after sawdust cover was used. The reduction of $\mathrm{CH}_{4}$ emission was the same, independently of the temperature regime. The highest reduction of $\mathrm{H}_{2} \mathrm{~S}$ and $\mathrm{CO}_{2}$ emissions when manure was covered occurred at $5{ }^{\circ} \mathrm{C}$, which was $100.0 \%(\mathrm{P}<0.01)$ and $95.5 \%(\mathrm{P}<0.01)$ lower, respectively, than uncovered manure. The highest reduction of $\mathrm{NH}_{3}$ emission was at $25^{\circ} \mathrm{C}$; it was $75.9 \%(\mathrm{P}$ $<0.01)$ lower than uncovered manure. Carbon monoxide emission from covered manure tended to increase only at $25^{\circ} \mathrm{C}$, but the opposite occurred at lower temperatures of 5 and $15^{\circ} \mathrm{C}$.

Straw cover. Straw cover had a significant impact on $\mathrm{H}_{2} \mathrm{~S}, \mathrm{NH}_{3}, \mathrm{CO}$, and $\mathrm{CO}_{2}$ emissions, and they also tended to affect $\mathrm{NO}$ emission. The emissions of $\mathrm{H}_{2} \mathrm{~S}, \mathrm{NH}_{3}$, and $\mathrm{CO}_{2}$ from covered manure were $92.1 \%(\mathrm{P}<0.01), 64.4 \%$ $(\mathrm{P}<0.01), 39.9 \%(\mathrm{P}<0.01)$, and 71.6\% $(\mathrm{P}<0.01)$ lower, respectively, than uncovered manure. The $\mathrm{CO}$ emission rates from manure with straw cover was 10.8 times $(\mathrm{P}<$ $0.01)$ higher than uncovered manure. The $\mathrm{NO}$ emission rates from manure with straw cover tended to be 50.4\% $(\mathrm{P}=0.13)$ lower than uncovered manure. However, straw cover was not the factor affecting $\mathrm{CH}_{4}$ emission.

The emissions of $\mathrm{H}_{2} \mathrm{~S}$ and $\mathrm{CO}_{2}$ decreased in all the temperature regimes after manure was covered with straw. The reduction of $\mathrm{NH}_{3}$ emission by covering manure was found only at 15 and $25^{\circ} \mathrm{C}$. A similar trend was observed for $\mathrm{NO}$ emission. The highest increase of $\mathrm{CO}$ emission after manure was covered occurred at $5{ }^{\circ} \mathrm{C}$, which was 3.2 times $(\mathrm{P}<0.01)$ higher than at $25^{\circ} \mathrm{C}$.

Plastic film cover. Plastic film cover had a significant impact on the emission of all measured gases: $\mathrm{CH}_{4}, \mathrm{NO}$, $\mathrm{H}_{2} \mathrm{~S}, \mathrm{NH}_{3}, \mathrm{CO}$, and $\mathrm{CO}_{2}$. Their emissions from covered manure were $91.5 \%(\mathrm{P}<0.01), 92.0 \%(\mathrm{P}<0.05), 78.1 \%$ $(\mathrm{P}<0.05), 54.7 \%(\mathrm{P}<0.01), 98.4 \%(\mathrm{P}<0.01)$, and $67.1 \%(\mathrm{P}<0.01)$ lower, respectively, than uncovered manure. 
The highest reduction of $\mathrm{CH}_{4}, \mathrm{NH}_{3}$, and $\mathrm{CO}$ emissions with covered manure was achieved at $5{ }^{\circ} \mathrm{C}$ rather than at 15 and $25^{\circ} \mathrm{C}$. In contrast, $\mathrm{H}_{2} \mathrm{~S}$ emission decreased only at 15 and $25^{\circ} \mathrm{C}$. The highest reduction of $\mathrm{NO}$ and $\mathrm{CO}_{2}$ emissions was at a higher temperature. At $25^{\circ} \mathrm{C}$, the reduction effect of cover on $\mathrm{NO}$ and $\mathrm{CO}_{2}$ emissions was $1.3(\mathrm{P}<0.05)$ and 1.5 times $(\mathrm{P}<0.01)$ higher, respectively, compared with $5^{\circ} \mathrm{C}$.

\section{DISCUSSION}

The results of this study showed that the impact of some floating covers on the emission of separate gases can be unequal. Covers can help to decrease the losses of some gases, but increase others. Furthermore, the effect of covers on gas emission varied depending on storage temperature.

In our study, methane emission decreased after covering manure with peat, sawdust, or plastic film compared with uncovered manure. This can be explained by the oxidation of $\mathrm{CH}_{4}$ inside the cover. Studies by Ambus and Petersen (2005), Petersen and Ambus (2006), Petersen et al. (2009) demonstrated that surface crust, formed on top of animal slurry, provides a habitat for $\mathrm{CH}_{4}$ oxidation activity, that is, microbial oxidation of $\mathrm{CH}_{4}$ to $\mathrm{CO}_{2}$. Therefore, the $\mathrm{CH}_{4}$ concentration can be reduced in the presence of surface crust. According to Petersen and Ambus (2006), a similar effect can happen in both natural surface crust and artificial floating cover. In our study, an ambiguous effect was found after using plastic film cover. The permeability of this cover was low (there were only small bleeders installed to release produced gases), so the cover mostly suppressed the dissolution of air oxygen into liquid manure, and $\mathrm{CH}_{4}$ oxidation activity should be poor. However, in our study, the mean $-91.5 \%$ reduction of methane emission was achieved after covering manure with plastic film. Analogous results ( $88 \%$ reduction) were detected by Hansen et al. (2006), who covered manure with polyethylene. Hudson et al. (2006) also confirmed that covers do not alter methane emission rates. It is possible that the effect of covering may vary not only depending on the type of cover but on other factors, such as storage time and the presence of inoculum of methanogenic microorganisms, which may also be important; however, it needs to be confirmed by future studies.

In our study, differences between $\mathrm{CH}_{4}$ emissions from manure with straw cover and uncovered manure were not significant. However, the results of some other studies were also controversial. In the study by VanderZaag et al. (2009), a reduction of $\mathrm{CH}_{4}$ emission from $24 \%$ to $28 \%$ was recorded after covering manure with straw. That could be the result of $\mathrm{CH}_{4}$ oxidation. However, Amon et al. (2006) and Berg et al. (2006) demonstrated that straw can increase $\mathrm{CH}_{4}$ emission. According to our study, the impact of straw cover on $\mathrm{CH}_{4}$ emission could depend on storage temperature.
In our study, various covers generally helped to decrease $\mathrm{NH}_{3}$ emission; this supports the concept that covering manure is beneficial. Portejoie et al. (2003) and Berg et al. (2006) also found that various materials used for covering manure have a reduction effect on $\mathrm{NH}_{3}$ emission. In our experiment, the best reduction of $\mathrm{NH}_{3}$ emission was achieved by covering manure with three types of covers: sawdust, straw, and plastic film cover. The highest average reduction of $\mathrm{NH}_{3}$ emission in our study was $73 \%$. A higher reduction (99\%) was detected by Portejoie et al. (2003) during storage of pig slurry covered with plastic film. They also found that $\mathrm{NH}_{3}$ emission was reduced by $93 \%, 77 \%$ to $100 \%$, and $93 \%$ to $98 \%$ when using oil, peat, and zeolite, respectively. The results most similar to those of our experiment were found in the study by Miner et al. (2003) where the cover, manufactured from recycled polyethylene chips topped with a geotextile layer containing zeolite particles, was tested and a reduction of $80 \%$ of $\mathrm{NH}_{3}$ emission was detected. Similarly, Bicudo et al. (2004) found a reduction of $\mathrm{NH}_{3}$ emission from swine manure after covering it with geotextile. A reduction of $\mathrm{NH}_{3}$ emission was also found by Hansen et al. (2006) after covering separated pig manure with polyethylene, but it was 4.6 times lower than our result after using plastic film cover.

As it was shown in our study, straw cover has a high reduction effect on $\mathrm{NH}_{3}$ emission (up to 64\%). In the study by VanderZaag et al. (2009), a higher reduction was found from $78 \%$ (for 15 -cm straw layer) to $90 \%$ (for 30-cm straw layer). However, in our study, the thickness of straw cover was several times lower than that in the abovementioned study; this might have caused the difference. For the straw, leca, peat, and sawdust cover tests, we used the same thickness to allow a comparison of the effect of different covers on the same gas emission. A thickness of covers similar to those in our study, were used by Portejoie et al. (2003) and a high emission reduction effect was found that supports the validity of our choice of cover thickness.

Our results showed that using covers can generally decrease $\mathrm{H}_{2} \mathrm{~S}$ emission (with the exception of peat). This agrees with the results by Bicudo et al. (2004), who found a reduction of $\mathrm{H}_{2} \mathrm{~S}$ flux after covering swine manure storage ponds with a geotextile cover. In our study, the highest reduction of $\mathrm{H}_{2} \mathrm{~S}$ emission was achieved by using straw, which was the most permeable of all the covers. The reduction of $\mathrm{H}_{2} \mathrm{~S}$ emission using floating covers can be explained by microbial oxidation. A permeable floating cover is similar to a biofilter. Bacteria and fungi living on biofilters (mainly made of wood chips) can oxidize volatile organic compounds and oxidizable inorganic gases, as well as vapors, including hydrogen sulfide and ammonia emission from swine facilities.

In our experiment, the temperature was the factor that affected gas emission, In general, the results of our study support the concept that gas emission rates increase at 
higher temperatures (Van der Stelt et al., 2007; Blunden and Aneja, 2008; You et al., 2008; Wang et al., 2010).

\section{CONCLUSIONS}

The results of our study showed that both cover and temperature have a noticeable impact on gas emission from liquid pig manure. Different covers had a different effect on separate gas emissions; the impact of using a cover was also associated with storage temperature. In general, the plastic film cover was the most efficient because this type of cover reduced the emissions of all measured gases. In this case, mean emission reductions were: $\mathrm{CH}_{4} 91.5 \%(\mathrm{P}<0.01), \mathrm{NO} 92.0 \%(\mathrm{P}<0.05), \mathrm{H}_{2} \mathrm{~S}$ $78.1 \%(\mathrm{P}<0.05), \mathrm{NH}_{3} 54.7 \%(\mathrm{P}<0.01), \mathrm{CO} 98.4 \%(\mathrm{P}$ $<0.01)$, and $\mathrm{CO}_{2} 67.1 \%(\mathrm{P}<0.01)$. Other covers had an inconsistent impact on separate gas emissions. However, covers generally helped to decrease $\mathrm{NH}_{3}, \mathrm{H}_{2} \mathrm{~S}$, and $\mathrm{CO}_{2}$ emissions.

\section{ACKNOWLEDGEMENTS}

The authors are grateful for the financial assistance provided by the Lithuanian University of Health Sciences, Medicine Academy Foundation for Science.

\section{LITERATURE CITED}

Ambus, P., and S.O. Petersen. 2005. Oxidation of 13C-labeled methane in surface crusts of pig and cattle slurry. Isotopes in Environmental Health Studies 41:125-133.

Amon, B., V. Kryvoruchko, T. Amon, and S. ZechmeisterBoltenstern. 2006. Methane, nitrous oxide and ammonia emissions during storage and after application of dairy cattle slurry and influence of slurry treatment. Agriculture Ecosystems \& Environment 112:153-162.

Berg, W., R. Brunsch, and I. Pazsiczki. 2006. Greenhouse gas emissions from covered slurry compared with uncovered during storage. Agriculture Ecosystems and Environment 112:129-134.

Bicudo, J.R., C.J. Clanton, D.R. Schmidt, W. Powers, L.D. Jacobson, and C.L. Tengman. 2004. Geotextile covers to reduce odor and gas emissions from swine manure storage ponds. Applied Engineering in Agriculture 20(1):65-75.

Blunden, J., and V.P. Aneja. 2008. Characterizing ammonia and hydrogen sulfide emissions from a swine waste treatment lagoon in North Carolina. Atmospheric Environment 42:3277-3290.

Brink, C., E. Van Ierland, L. Hordijk, and C. Kroeze. 2005. Costeffective emission abatement in agriculture in the presence of interrelations: cases for the Netherlands and Europe. Ecological Economics 53:59-74.

Dinuccio, E., W. Berg, and P. Balsari. 2008. Gaseous emissions from the storage of untreated slurries and the fractions obtained after mechanical separation. Atmospheric Environment 42:2448-2459.

European Commission. 2011. Analysis of methodologies for calculating greenhouse gas and ammonia emissions and nutrient balances. Publications Office of the European Union, Luxembourg.
EEA. 2009. EEA air pollutant emission inventory guidebook 2009 - technical guidance to prepare national emission inventories. European Environment Agency (EEA), Copenhagen, Denmark.

Hansen, M.N., K. Henriksen, and S.G. Sommer. 2006. Observations of production and emission of greenhouse gases and ammonia during storage of solids separated from pig slurry: effects of covering. Atmospheric Environment 40:4172-4181.

Hudson, N., D. Duperouzel, and S. Melvin. 2006. Assessment of permeable covers for odour reduction in piggery effluent ponds. 1. Laboratory-scale trials. Bioresource Technology 97:2002-2014.

IPCC. 2006. 2006 IPCC Guidelines for national greenhouse gas inventories, prepared by the Intergovernmental Panel on Climate Change (IPPC) National Greenhouse Gas Inventories Programme. Eggleston, H.S., L. Buendia, K. Miwa, T. Ngara, and K. Tanabe (eds.) Institute for Global Environmental Strategies (IGES), Hayama, Japan.

Miner, J.R., F.J. Humenik, J.M. Rice, D.M.C. Rashash, C.M Williams, W. Robarge, et al. 2003. Evaluation of a permeable, 5 $\mathrm{cm}$ thick, polyethylene foam lagoon cover. Transactions of the ASAE 46:1421-1426.

Ndegwa, P.M., A.N. Hristov, J. Arogo, and R.E. Sheffield. 2008 A review or ammonia emissions mitigation techniques for concentrated animal feeding operations. Biosystems Engineering 100:453-469.

Peters, J., S.M. Combs, B. Hoskins, J. Jarman, J.L. Kovar, M.E. Watson, et al. 2003. Recommended methods of manure analysis. Cooperative Extension Publishing, Madison, Wisconsin, USA.

Petersen, S.O., and P. Ambus. 2006. Methane oxidation in pig and cattle slurry storages, and effects of surface crust moisture and methane availability. Nutrient Cycling in Agroecosystems 74:1-11.

Petersen, S.O., B. Amon, and A. Gattinger. 2005. Methane oxidation in slurry storage surface crusts. Journal of Environmental Quality 34:455-461. doi:10.2134/jeq2005.455.

Petersen, S.O., M. Skov, P. Drøscher, and A.P.S. Adamsen 2009. Pilot scale facility to determine gaseous emissions from livestock slurry during storage. Journal of Environmental Quality 38:1560-1568.

Portejoie, S., J. Martinez, F. Guiziou, and C.M. Coste. 2003. Effect of covering pig slurry stores on the ammonia emission processes. Bioresource Technology 87:199-207.

Sommer, S.G., J.E. Olesen, S.O. Petersen, M.R. Weisbjerg, L. Valli, L. Rodhe, et al. 2009. Region-specific assessment of greenhouse gas mitigation with different manure management strategies in four agroecological zones. Global Change Biology 15:2825-2837.

Van der Stelt, B., E.J.M. Temminghoff, P.C.J. Van Vliet, and W.H Van Riemsdijk. 2007. Volatilization of ammonia from manure as affected by manure additives, temperature and mixing. Bioresource Technology 98:3449-3455.

VanderZaag, A.C., R.J. Gordon, R.C. Jamieson, D.L. Burton, and G.W. Stratton. 2009. Gas emissions from straw covered liquid dairy manure during summer storage and autumn agitation. Transactions of the ASAE 52:599-608.

Wang, J., C. Duan, Y. Ji, and Y. Sun. 2010. Methane emissions during storage of different treatments from cattle manure in Tianjin. Journal of Environmental Sciences 22:1564-1569.

Webb, J., M. Ryan, S.G. Anthony, A. Brewer, J. Laws, M.F. Aller, et al. 2006. Cost-effective means of reducing ammonia emissions from UK agriculture using the NARSES model. Atmospheric Environment 40:7222-7233.

You, Y.B., H.M. Dong, Z.P. Zhu, X.P. Tao, and Y.X. Chen. 2008 Experiments on influencing factors of methane emissions from beef cattle manure stack. Transactions of the ASAE 24(12):168-172. 